\title{
Reflections on dignified life and death
}

José Luis Sandoval-Gutiérrez*

Instituto Nacional de Enfermedades Respiratorias, Sub-directorate of Diagnostic and Paramedic Auxiliary Services, Ciudad de México, Mexico

If death did not exist, I would invent it to live intensely Anonymous In this life there's nothing new in dying, Nor, of course, is living any newer.

YESENIN

A recent study reports that less than $20 \%$ of pediatricians have a positive attitude towards death. ${ }^{1}$ The National Academy of Medicine of Mexico has presented a posture in relationship with decisions about end of life, ${ }^{2}$ which motivates to formulate a reflection on the subject.

In a thanatology course in a private hospital, a female oncology patient-participant commented "I accept death, but I don't accept pain". Those wise words of a woman in the third decade of life, who did not finish the course because a few weeks later she died and her sister finished it in her honor, have remained in my memory in recent years. She, a woman with college and postgraduate education, a bank manager, who fought against a breast cancer with metastasis, referred in the academic session before health personnel that was studying the diploma course, that her doctors did not want to increase the morphine dose because of the risk of becoming addicted; in a playful tone she assured us that she was going to die before she could manage to develop such addiction.

Owing to their professional training, doctors have considered death as the great enemy to defeat and that we must use all physical means and technology to avoid it in our patients. Innovations in intensive therapy, training in this specialty by doctors and nurses, the demands of patients and relatives to give everything possible to the patient regardless of age or disease progression situation have caused that new students do not have an adequate reflection about the inevitability of this human condition.

I remember a 93-year-old patient who was on mechanical ventilation in a public hospital due to a pneumonia, who also had kidney and liver failure. His daughter, a doctor, commented: "My dad, though he looks old, loves life, so please try everything on him".

The challenges in the years to come are to educate and promote the concept of dignified life and death. No one should experience pain if the conditions and medications to avoid it exist; nobody should go through suffering if there are places to handle it. Not continuing with an advanced treatment that has not yielded results is not an act of cowardice or negligence; on the contrary, it is an intelligent and correct attitude in the face of an imminent reality.

\section{González Martínez comments: ${ }^{3}$}

A competent medicine only in scientific terms cannot help the patient cope with health loss or find the meaning of suffering; in addition to the scientific capacity, doctors need to hear the stories of their patients, understand and glorify their meanings and act to their benefit. Verbal and nonverbal expressions that arise in the scenario of human and technical encounter between a doctor and a patient during medical consultation, put him/her on the right track to establish an accurate diagnosis and effective treatment; hence, for the exercise of a human medicine that is technically and socially effective and based on technological progress, it seems increasingly indispensable to solidly train doctors in the anthropological and ethical aspects of their profession, as well as training them to master skills and abilities. No technology, however useful it may be, can replace an intelligent and skillful doctor that employs his/her intellectual capacity and
Correspondence:

*José Luis Sandoval-Gutiérrez

E-mail: sandovalgutierrez@gmail.com
Gac Med Mex. 2019;155:305-306

Contents available at PubMed www.gacetamedicademexico.com 
senses to communicate with his/her patient in an effective way during medical consultation, obtaining from patient history and physical examination data to develop an accurate diagnosis and, consequently, prescribe an efficacious treatment to the patient; most part of therapeutics is through the doctor.

\section{As Gutiérrez Samperio says: ${ }^{4}$}

The concept of palliative medicine is often wrong: it is considered that indicating and using it is equivalent to "doing nothing", which is absolutely far from reality. The purpose is to suppress pain and other discomforting symptoms, avoid (as far as possible) suffering and, this way, improve quality of life, in order for the patient to have the will to preserve a life that can be considered dignified.
It is important for the doctor of this millennium to extensively reflect on the concepts of life, death and dignity, to the benefit of patients and of his/her own professional practice.

\section{References}

1. Sánchez-Sánchez LM, López-Córdova ED, Siller-Gómez P. Actitud del personal médico de un servicio de pediatría ante la muerte de los pacientes. Gac Med Mex. 2018;154(2):152-160.

2. Mansilla-Olivares A, López-Bárcena J, Plancarte-Sánchez R, Valenzuela-Gómez-Gallardo F, Rojo J, Meneses-González F, et al. Postura de la Academia Nacional de Medicina de México en relación con las decisiones sobre el final de la vida. Gac Med Mex. 2018;154(6):732-736.

3. González-Martínez JF, León-Paoletti Al. El reto de ser médico. Segunda edición. Ediciones y Servicios Editoriales: 2017.

4. Gutiérrez-Samperio C. Medicina paliativa. Ciruj Gen 2017;39(4):251-256. 